\title{
Is cytoimmunological monitoring a safe follow-up method for heart transplantation patients?
}

\author{
Faruk Cingoz, Celalettin Gunay, Bilgehan Savas Oz, Mehmet Arslan \\ Department of Cardiovascular Surgery, Gulhane Military Medical Academy, Ankara, Turkey \\ Kardiochirurgia i Torakochirurgia Polska 2014; 11 (1): 48-51
}

\begin{abstract}
The aim of the study is to show the effects of cytoimmunological monitoring and its role in the patient's follow-up period after heart transplantation.

Material and methods: Between 2002 and 2009, 8 patients underwent heart transplantation at Gulhane Military Medical Academy Hospital. Seven patients were male. The average age was $43 \pm 12$ years. Donor hearts were implanted orthotopically in all patients. The patients were then subjected to cytoimmunological monitoring and endomyocardial biopsy. 431 laboratory blood tests were carried out for all patients to analyze their cytoimmunological profiles and diagnose a possible infection or rejection.

Results: The total and average follow-up periods were $17.5 \mathrm{pa}$ tient years and $30 \pm 36$ months (1-120 months), respectively. The first patient had two rejection episodes in 3 months. A viral infection was diagnosed in the third patient, who had painful muscle spasms in both lower limbs and the CD4/CD8 ratio was below 0.4 . In the fourth patient, the CD4/CD8 ratio suddenly increased and a urinary infection was diagnosed. Only one patient passed away in the early period (less than 30 days). Four patients died because of an infection or hemodynamic deterioration within three months.

Conclusions: Cytoimmunological monitoring is a simple and effective technique of evaluating the patient's immunological profile. It may provide an adjunctive laboratory test and may decrease the number of endomyocardial biopsies.
\end{abstract}

Key words: heart transplantation, cytoimmunologic monitoring.

\section{Introduction}

Christian Bernard performed the first human heart transplantation to a 54-year-old man who suffered from endstage heart failure. The patient died from pseudomonas pneumonia 18 days after the operation [1]. This case exposed

\section{Streszczenie}

Celem pracy jest przedstawienie efektów monitorowania cytoimmunologicznego i jego roli w pooperacyjnym leczeniu pacjenta po przeszczepie serca.

Materiat i metody: W latach 2002-2009 w szpitalu Wojskowej Akademii Medycznej w Gulhane u 8 pacjentów, w tym 7 mężczyzn, dokonano przeszczepu serca. Średni wiek pacjentów wynosił $43 \pm 12$ lat. Serca dawców wszczepiono u wszystkich pacjentów ortotopowo. Następnie poddano ich monitorowaniu cytoimmunologicznemu i biopsji serca (EMB). U wszystkich pacjentów wykonano łącznie 431 laboratoryjnych badań krwi celem przeanalizowania profili cytoimmunologicznych oraz rozpoznania możliwej infekcji lub odrzucenia przeszczepu.

Wyniki: Pełny i średni okres kontroli pooperacyjnej wynosit, odpowiednio, 17,5 pacjentolat, $30 \pm 36$ miesięcy (1-120 miesięcy). Pierwszy pacjent miał dwa incydenty odrzuceniowe w ciągu 3 miesięcy. $U$ trzeciego pacjenta stwierdzono infekcję wirusową - zanotowano u niego skurcze mięśni w obu dolnych kończynach, a proporcja CD4/CD8 wynosiła poniżej 0,4. U czwartego pacjenta stosunek CD4/CD8 wzróst nagle i rozpoznano infekcję układu moczowego. We wczesnym okresie pooperacyjnym (mniej niż $30 \mathrm{dni}$ ) zmarł tylko jeden pacjent. Czterech kolejnych zmarło z powodu infekcji lub pogorszenia hemodynamicznego w ciągu 3 miesięcy.

Wnioski: Monitorowanie cytoimmunologiczne jest łatwą do przeprowadzenia i efektywną techniką oceny immunologicznego profilu pacjenta. Może ono stanowić uzupełniający test laboratoryjny i przyczynić się do zmniejszenia liczby biopsji serca.

Słowa kluczowe: transplantacja serca, monitorowanie cytoimmunologiczne.

the risk of rejection and opportunistic infections following a heart transplantation. Consequently, it was proposed that mortality and morbidity after a heart transplantation is caused mainly by those two factors. Endomyocardial biopsy (EMB) is the most sensitive method for an early diagnosis of rejection [2]. It is still commonly used for the follow-up of

Address for correspondence: Dr. Faruk Cingoz, Associate Professor of Cardiothoracic Surgery, GATA Subay Lojmanlari, Rieder Apt. 5/22, 06018 Etlik, Ankara, Turkey, phone: +90 312 3045220, fax: +90 312 3045200, e-mail: fcingoz@gata.edu.tr 
patients around the world. EMB is an invasive method and may prove ineffective in gathering information about the transplanted heart. Moreover, EMB does not provide enough data on infection in heart-transplanted patients.

As an alternative to EMB, new ideas for using non-invasive diagnostic methods to follow the transplanted patient have emerged in the last years [2-5]. Cytoimmunological monitoring (CIM), which explains the immunological response of the body to the transplanted heart, gives important clues about the rejection. This method, developed by Hammer and colleagues in 1984, involves phenotyping the lymphocytes according to their surface antigens by treating them with monoclonal antibodies [5]. It has been suggested that CIM can decrease the EMB frequency and is sensitive enough to diagnose acute rejection or infection. According to research, CIM is sensitive to histopathological changes in the transplant, easy, non-invasive, and can be successfully used as an alternative to EMB [5-8]. Specifically, CIM can provide information about the rejection or infection, and guide the transplant team to use more invasive methods for a more definitive diagnosis. CIM may also provide information about the dosage of immune-suppressive therapy [4-13]. In this study, we aim to present our findings and updated data about CIM, which is one of the most interesting non-invasive techniques used to provide important information about the patient's immunological status after a heart transplantation.

\section{Material and methods}

Eight heart transplantations were carried out in our department between 2002 and 2009. Seven patients were male and the average age of patients was $43 \pm 12$ years. Donor hearts were implanted orthotopically in all patients.

\section{Preoperative follow-up}

All patients were hospitalized in order to assess their basal levels and data. Blood samples were taken from patients at clinical controls (every month) and immediately after the operation, and all major blood parameters were evaluated.

\section{Cytoimmunological follow-up}

Beginning on day 2 after the surgery, every other day during the $1^{\text {st }}$ month, three times a week during the $2^{\text {nd }}$ month, twice a week during the $3^{\text {rd }}$ month, and once a week between the $3^{\text {rd }}$ and $6^{\text {th }}$ month, blood samples were drawn from a peripheral vein in sterile condition to tubes with EDTA. After processing in the immunological laboratory, lymphocytes were divided into subgroups, such as non-activated lymphocytes, plasmocytes, lymphoblasts, activated lymphocytes, and large granular lymphocytes.

\section{Evaluation of cytoimmunological monitoring and rejection criteria}

Lymphocyte antigens investigated by monoclonal antibodies were obtained to show the heart recipient's im- munological panel. These parameters include CD3 (total lymphocyte amount), CD4 (helper T lymphocytes), CD8 (cytotoxic and suppressor T lymphocytes), CD19/20 (mature B cells), CD25 (interleukin-2 receptor antigen), CD45 (all leucocytes), CD16/56 (natural killer cell), CD54 (adhesion molecule), and CD57 (activated T cells). All these receptors are vital to understand the recipient's immunological response after the transplantation [8-10].

The aim of the immunosuppressive treatment is to reduce the number of lymphocytes and to suppress the specific immune response. For this reason, the number of lymphocytes in the peripheral blood smear is important. An activated T-lymphocyte count of more than $5 \%$ is generally associated with rejection, but an increased ratio of lymphocyte/PMNL, and thus an increase in the lymphocyte amount or borderline peripheral blood smear by more than $40 \%$ was for us an indication of rejection. An increased activated lymphocyte count of more than $5 \%$, CD25 of more than $10 \%$, CD57 of more than $20 \%$ was viewed by us as an indication of acute rejection. A ratio of CD4/CD8 of more than 1.2 and more than $14 \%$ of NK cells was considered by us as an acute bacterial infection, while a ratio of CD4/ CD8 of less than 0.4 or a large granular lymphocyte amount of more than $15 \%$ was considered by us as an acute viral infection [4-16].

\section{Postoperative follow-up and treatment}

Patients underwent a classical immunosuppressive treatment, involving the administration of cyclosporine (5-10 mg/kg per day), corticosteroid (1 mg/kg per day), and azathioprine (2-4 mg/kg per day). None of the patients required a polyclonal or monoclonal antithymocyte drug to be administered for immunosuppressive induction preoperatively. In acute rejection, initially, a high-dose treatment with methylprednisolone ( $1 \mathrm{~g}$ per day) was administered via a peripheral vein for 3 days. If it was unsuccessful, antithymocyte globulin (1.5 mg/kg for 7-14 days) was administered.

\section{Results}

The total follow-up time was 17.5 patient years, while the average follow-up time was $30 \pm 36$ months (1-120 months). Donor hearts were implanted in all patients orthotopically. Only one patient passed away because of hemodynamic deterioration in the early period (less than 30 days). Three patients died within the second month. All other patients were alive in the first year. The treatment team using CIM, in addition to their clinical findings, continues their periodical laboratory follow-up. 431 laboratory blood tests have been carried out for all patients. Significant rejection clues were noted with CIM in one patient. Steroid treatment was initiated after the rejection criteria were met by CIM. EMB was performed after the initial steroid treatment in order to evaluate the effects of the treatment and to assess the type of possible rejection. No sign of rejection was present in the transplanted heart on EMB; the subsequent CIM results were insignificant as well. The patient was alive in 
his third postoperative year and had no cardiac problems within this period. There were no signs of rejection in the third heart transplant patient during the first month, but later an acute viral infection was suspected because of painful muscle spasms especially in the lower extremities, accompanied by a decrease of the CD4/CD8 ratio. Additionally, a very high value of anti-HCV Tip-I IgM was indicated in antibody titration tests. Gancyclovir treatment $(5 \mathrm{mg} / \mathrm{kg}$ per day) was prescribed to the patient and the low $\mathrm{Mg}$ level was improved, while the symptoms subsided entirely by the end of the second month. The patient was in his second postoperative year and he had an active lifestyle. The fourth patient had no signs of rejection, but he showed signs of an infection on the $40^{\text {th }}$ postoperative day. The CD4/ CD8 ratio was high and we considered it as an indication of an acute bacterial infection. The patient was diagnosed with a urinary tract infection and later he died because of sepsis. Other patients did not show signs of infection or rejection.

\section{Discussion}

A heart transplantation is the last treatment option for end-stage heart failure when medical or surgical treatment fails. It has a high cost and is often followed by various early and late complications (rejection and infection). In the 1970s, heart transplantations became less frequent because of the associated high mortality rate. However, the ongoing immunological research contributed to restarting heart transplantations on a larger scale. A critical landmark for performing heart transplantations was the introduction of cyclosporine as an immunosuppressive agent [13]. The most risky period of infection and rejection for heart transplant recipients is the first 6 months after the operation [3-11]. For the early diagnosis of rejection in posttransplant patients, EMB is considered the most sensitive method, and it still remains the gold standard. However, EMB is an invasive method, which is used in patients receiving immunosuppressive drug therapy at the same time and whose susceptibility to infections is at a higher level. Moreover, mechanical complications resulting from this invasive procedure and the requirement of hospitalization in order to perform catheterization add to its weak points. Also it requires serious teamwork and involves the necessity to obtain a specimen from the appropriate zone of the transplanted heart for an optimal result.

Acute rejection is responsible for $25 \%$ of deaths after heart transplantation [2]. Besides EMB, some non-invasive diagnostic methods (MRI, CT, ECG, echocardiography, CIM) have been developed in order to diagnose and treat the rejection before heart failure symptoms become apparent. Unfortunately, none of these methods can provide an alternative to EMB in terms of accuracy [3-5]. The latest developments in techniques used for the evaluation of immunological response in vitro have encouraged many studies into CIM, which reflects the body's immunological response to the transplanted heart [3-9]. For that reason, it has been used more extensively in recent years in the early diagnosis of rejection $[15,16]$.
The specific immune response to the transplanted heart is mediated by T-lymphocytes and there is a marked increase in the amount of leucocytes, lymphocytes, lymphoblasts and prolymphoblasts in acute rejection $[17,18]$. Although the immunological pathophysiology of acute rejection is not well known, the inflammatory process, which is mediated by cellular immunity, is thought to be responsible [17-22]. Lymphocyte activation without rejection can occur in some clinical situations (especially infections) and can also activate lymphocytes [18]. For that reason, the differentiation between an infection and a rejection poses a serious problem in patients who are subjected to CIM in the follow-up period. Therefore, CIM seems to be helpful in a two-fold way: it helps to indicate a rejection and to differentiate a rejection from an infection. It is generally accepted that CIM is sensitive enough to detect a rejection and may reduce the frequency of EMBs.

The immunosuppressive agents used in transplant recipients will suppress cellular immunity and will make changes in the immunological system. The effectiveness of these drugs is generally controlled from their plasma levels. Yet, following the lymphocyte activation with CIM might also provide reliable information. According to the latest literature, CIM, which is simple, useful, non-invasive and sensitive to histopathological changes, is now more extensively used as an alternative to EMB [24]. If, however, a rejection is suspected, EMB is indispensable in determining the severity of rejection [2].

We followed all patients' rejection process clinically with CIM, but we still preferred to use EMB to diagnose rejection in suspected patients. We do believe, however, that if CIM results are evaluated together with the patient's symptoms, clinical findings, ECG and echocardiogram results, they can provide valuable clues about the rejection [3-5].

The CD4/CD8 ratio obtained by CIM is important in differentiating an infection from a rejection. It has a sensitivity level of $85-100 \%$, a specificity level of $90-94 \%$, and a positive predictive value of $85.7 \%$. The CD4/CD8 ratio of 1.5 , the level of blast cells at $70 \%$ and the active lymphocyte value of $>20 \%$ are important determinants for a rejection [15-24]. In viral infections, this ratio becomes 1 (and in some cases < 0.1 ) and the amount of large granular lymphocytes increases greatly. For patients treated with prednisolone and cyclosporine, a sudden decrease in the CD4/CD8 ratio resembles that of viral infections, in which the etiology is generally CMV or EBV [20-26].

There is a relationship between infections and rejections in the first 5 weeks after cardiac transplantation: the CD4/IL-2 ratio, and the sensitivity and specificity of this ratio were calculated as $79 \%$ and $97 \%$, respectively. In normal situations, IL-2 is not secreted when T-lymphocytes are not activated, because it is only secreted from the activated T-lymphocytes. CIM gives significant clues if the number of T helper cells that have the IL-2 receptor is $20 \%$ above the total $T$ cell count and their absolute count is more than 120 cells/ml $[22,23]$. The assessment of active T-lymphocytes gives important information about the rejection. In 
the rejection period, active lymphocyte's cytosol becomes basophilic and changes to a blast cell. The diagnosis of lymphocyte activation can be reached by the ratio of activated lymphocytes to non-activated lymphocytes. A value over $5 \%$ is significant for a rejection and it is determined that the lymphocyte activation, histologically, has the same findings as myocyte necrosis in the transplanted heart. When $5 \%$ of activated lymphocytes are present, CIM's sensitivity and specificity are at the level of $29-95 \%$ and $73-97 \%$, respectively [22-26]. In our clinical cases, we aimed to establish the diagnosis with clinical, electrocardiographic and echocardiographic findings, if CIM results made us consider a rejection. Whenever we suspected a rejection, we started the steroid attack treatment, followed by administering antibiotics after the etiologic identification by antibody titration.

In recent years, studies on CIM have focused mainly on establishing the rejection criteria. There is no evidence for a relationship between CIM and chronic rejection, when $\mathrm{CIM}$ yields effective information about an acute rejection. The confidence of CIM after a heart transplantation decreases with time.

Consequently, despite our small number of cases (431 samples were evaluated), we think that CIM - if used with other non-invasive methods in the first 3-6 months after surgery - is a useful method that increases the patient's comfort, may decrease the EMB frequency, and helps to determine the doses of immunosuppressive drugs in patients who are already subjected to a high-dose immunosuppressive treatment and are, therefore, at risk of developing infections.

\section{References}

1. Barnard CN. A human cardiac transplant: an interim report of a successful operation performed at Groote Schuur Hospital, Capetown. S Afr Med J 1967; 41: 1271-1274.

2. Costanzo MR, Dipchand A, Starling R, Anderson A, Chan M, Desai S, Fedson S, Fisher P, Gonzales-Stawinski G, Martinelli L, McGiffin D, Smith J, Taylor D, Meiser B, Webber S, Baran D, Carboni M, Dengler T, Feldman D, Frigerio M, Kfoury A, Kim D, Kobashigawa J, Shullo M, Stehlik J, Teuteberg J, Uber P, Zuckermann A, Hunt S, Burch M, Bhat G, Canter C, Chinnock R, Crespo-Leiro M, Delgado R, Dobbels F, Grady K, Kao W, Lamour J, Parry G, Patel J, Pini D, Towbin J, Wolfel G, Delgado D, Eisen H, Goldberg L, Hosenpud J, Johnson M, Keogh A, Lewis C, O'Connell J, Rogers J, Ross H, Russell S, Vanhaecke J; International Society of Heart and Lung Transplantation Guidelines. The International Society of Heart and Lung Transplantation Guidelines for the care of heart transplant recipients. J Heart Lung Transplant 2010; 29: 914-956.

3. Baughman KL. Monitoring of allograft rejection. In: Baumgartner WA, Reitz BA, Achuff SC (eds.). Heart and Heart-Lung Transplantation. WB Saunders CO, Philadelphia 1990; p. 86.

4. Kemkes BM, Schütz A, Engelhardt HM, Brandl U, Breuer M. Noninvasive methods of rejection diagnosis after heart transplantation. J Heart Transplant 1992; 11 (4 Pt 2): S221-231.

5. Hammer C, Reichenspurner H, Ertel W, et al. Cytological and immunologic monitoring of cyclosporine-treated human heart recipients. Heart Transplant 1984; 3: 224-231.
6. Reader JA, Burke MM, Counihan P, Kirby JA, Adams S, Davies MJ, Pepper JR. Noninvasive monitoring of human cardiac allograft rejection. Transplantation 1990; 50: 29-33.

7. Fieguth HG, Haverich A, Schäfers HJ, Wahlers T, Herrmann G, FrimpongBoateng K, Cremer J, Kemnitz J, Borst HG. Cytoimmunologic monitoring in early and late acute cardiac rejection. J Heart Transplant 1988; 7: 95-101.

8. McNally CM, Luckhurst E, Penny R. Cell free serum interleukin-2 receptor levels after heart transplantation. J Heart Lung Transplant 1991; 10: 769-774.

9. Pellettier LC, Montplaisir S, Pellettier G, Castonguay Y, Harvey P, Dyrda I, Solymoss CB. Lymphocyte subpopulation monitoring in cyclosporin treated patient following heart transplantation. Ann Thorac Surg 1988; 45: 11-15.

10. Ertel W, Reichenspurner $\mathrm{H}$, Hammer $\mathrm{C}$, et al. Cytoimmunologic monitoring: a method to reduce biopsy frequency after cardiac transplantation. Transplant Proc 1985; 17: 204-206.

11. Winjgaard PLJ, Doornewaard H, van der Meulen A, Plomp S, Gmelig Meyling $\mathrm{FH}$, de Jonge $\mathrm{N}$, Schuurman $\mathrm{HJ}$. Cytoimmunologic monitoring as an adjunt in monitoring rejection after hearttransplantation: Result of a 6 year follow up in heart transplant recipients. J Heart Lung Transplant 1994; 13: 869-875.

12. Moretta L, Mingari MC, Moretta A. Human T cell subpopulations in normal and pathologic conditions. Immunol Rev 1979; 45: 163-193.

13. Oyer PE, Stinson EB, Jamieson SA, et al. Cyclosporin A in cardiac allografting: a preliminary experience. Transplant Proc 1983; 15: 1247.

14. Cingoz F, Gunay C, Ozal E, Tatar H. Repeated paracentesis for treatment renal failure after heart transplantation in patient with ascites. J Card Surg 2007; 22: 1-2.

15. Billingham ME, Cary NR, Hammond ME, Kemnitz J, Marboe C, McCallister HA, Snovar DC, Winters GL, Zerbe A. A working formulation for the standardization of normenclature in the diagnosis of heart and lung rejection: Heart Rejection Study Group. J Heart Transplant 1990; 9: 587-593.

16. Stewart S, Winters GL, Fishbein MC, Tazelaar HD, Kobashigawa J, Abrams J, Andersen CB, Angelini A, Berry GJ, Burke MM, Demetris AJ, Hammond E, Itescu S, Marboe CC, McManus B, Reed EF, Reinsmoen NL, Rodriguez ER, Rose AG, Rose M, Suciu-Focia N, Zeevi A, Billingham ME. Revision of the 1990 working formulation for the standardization of nomenclature in the diagnosis of heart rejection. J Heart Lung Transplant 2005; 24: 1710-1720.

17. Hanson CA, Boiling SF, Stoolman LM, Schlegelmilch JA, Abrams GD, Miska PT, Deeb GM. Cytoimmunologic monitoring and heart transplantation. J Heart Transplant 1988; 7: 424-429.

18. Blumberg RS, Schooley RT. Lymphocyte markers and infectious diseases. Semin Hematol 1985; 22: 81-114.

19. Jondai $M$, Holm G, Wigzell $H$. Surface markers on human $T$ and $B$ lymphocytes. J Exp Med 1972; 136: 207-215.

20. Luckhurst E, McNaaly C, Spratt P, Chang V, Penny R. T lymphocyte function following cardiac transplantation. Transplant Proc 1986; 18: 352-354.

21. Kung PC, Goldstein G, Reinherz EL, Schlossmann SF. Monoclonal antibodies defining distinctive human T cell antigens. Science 1979; 206: 347-350.

22. May RM, Cooper DKC, Du Toit ED, Richard B. Cytoimmunologic monitoring after heart and heart-lung transplantation. J Heart Transplant 1990; 9: 133-135.

23. Hammer C, Klanke D, Lersch C, et al. Cytoimmunologic monitoring (CIM) for differentiation between cardiac rejection and viral, bacterial, or fungal infection: its specifîcity and sensitivity. Transplant Proc 1989; 21: 3631-3633.

24. Dummer JS, Bound LM, Singh G, Atchison RW, Kapadia SB, Ho M. The effect of Cytomegalovirus and Epstein-Barr virus infection on T lymphocyte subsets in cardiac transplant patients on cyclosporine. Am J Med 1984; 77: 179-184.

25. Roodman ST, Miller LW, Tsai CC. Role of interlukin-2 receptors in immunologic monitoring following cardiac transplantation. Transplantation 1988; 45: 1050-1056.

26. Westra AL, Heijn AA, Uyama T, Prop J, Wildevuur CRH. Morphologic activation of lymphocytes in blood during rejection of heart and lung grafts in rats. Transplantation 1991; 51: 705-711. 